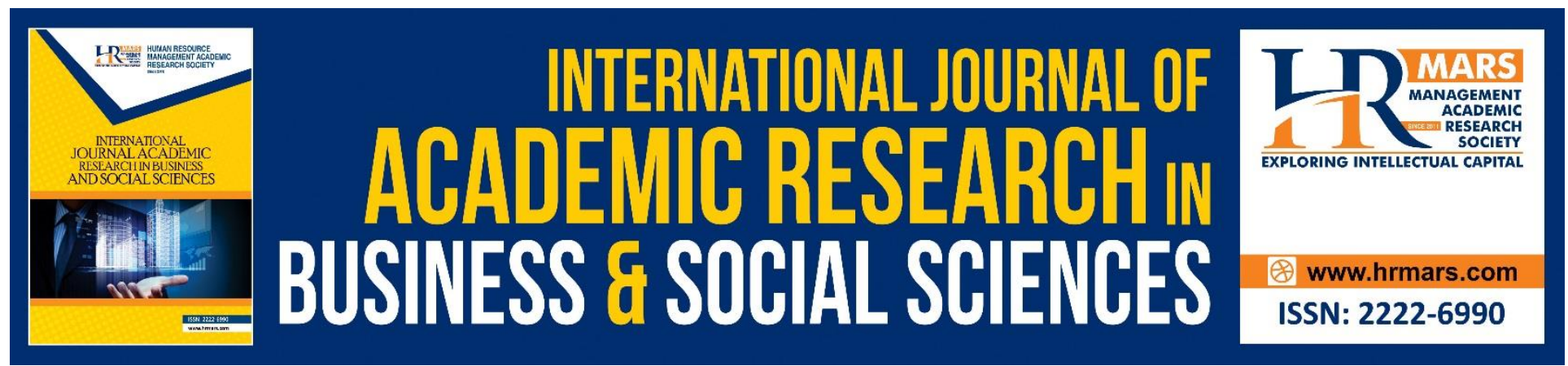

\title{
Examining the Causes of Plastic Bags Usages and Public Perception about its Effects on the Natural Environment
}

\author{
Muhammad Umar Ahsan, Muhammad Nasir, Jawad Abbas
}

To Link this Article: http://dx.doi.org/10.6007/IJARBSS/v10-i10/7919

DOI:10.6007/IJARBSS/v10-i10/7919

Received: 27 July 2020, Revised: 30 August 2020, Accepted: 21 September 2020

Published Online: 14 October 2020

In-Text Citation: (Ahsan, Nasir, \& Abbas, 2020)

To Cite this Article: Ahsan, M. U., Nasir, M., \& Abbas, J. (2020). Examining the Causes of Plastic Bags Usages and Public Perception about its Effects on the Natural Environment. International Journal of Academic Research in Business and Social Sciences. 10(10), 80-96.

\section{Copyright: (c) 2020 The Author(s)}

Published by Human Resource Management Academic Research Society (www.hrmars.com)

This article is published under the Creative Commons Attribution (CC BY 4.0) license. Anyone may reproduce, distribute, translate and create derivative works of this article (for both commercial and non-commercial purposes), subject to full attribution to the original publication and authors. The full terms of this license may be seen at: $\underline{\text { http://creativecommons.org/licences/by/4.0/legalcode }}$

Vol. 10, No. 10, 2020, Pg. 80 - 96

Full Terms \& Conditions of access and use can be found at http://hrmars.com/index.php/pages/detail/publication-ethics 


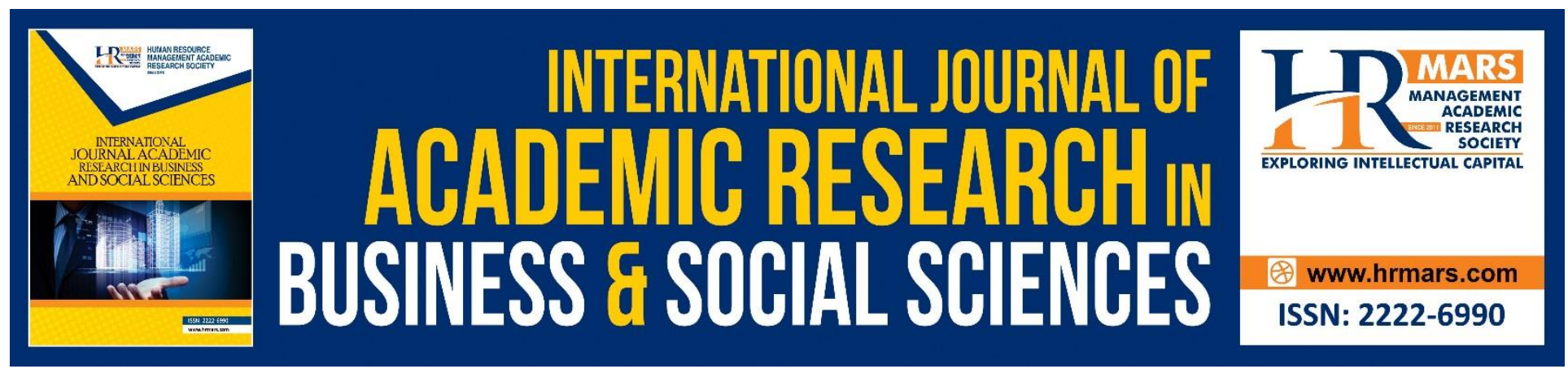

\title{
Examining the Causes of Plastic Bags Usages and Public Perception about its Effects on the Natural Environment
}

\author{
Muhammad Umar Ahsan, Muhammad Nasir, Jawad Abbas \\ Department of Business Administration, Iqra University, Islamabad Campus, Pakistan. \\ Email:muhammad31577@iqraisb.edu.pk,umarahsan180@gmail.com
}

\begin{abstract}
Plastic bags are one of the most commonly used products in our daily life. The current research aims to investigate the common causes of its usage and public perception about its effect on the natural environment, including land, air and water pollution. The researchers collected data from 173 individuals from Islamabad and Rawalpindi cities of Pakistan using a non-probability convenience sampling technique. Empirical results reveal that $53 \%$ of participants are extensively using plastic bags. Moreover, to dispose of, $46.82 \%$ prefer to openly dump it while $30.63 \%$ prefer to burn. Most of the respondents (30.63\%) valued the significant role of TV and Radio in communicating the unfavourable effects of plastic bag wastes. Interestingly, an equal number of participants opined increase and decrease trend in the usage of plastic bags however most of them considered cloth bags as an alternative solution for the problem. This study can help to access the severity of the problem, identify the reasons and provide alternative solutions considering public perspective located in the targeted region.
\end{abstract}

Keywords: Plastic Bags, Pollution, Natural Environment, Waste.

\section{Introduction}

For a long time, countries all over the world are using plastic as an accidental innovation in hydrocarbons. Plastic bags were first manufactured in the 1970s (Williamson, 2003) and their use went on increasing day by day (Mahmood et al., 2020). In the last quarter of the $20^{\text {th }}$ century, an enormous amount of products were created using plastics (Sugii, 2008). At first, it looked as convenient, cheap, flexible and long-lasting resource ranging from the production of electric appliances body to single sheet plastic bags. Most of these bags are being disposed of as waste after single time usage (Moharam \& Maqtari, 2014). The United States petrochemical industries first presented and encouraged the production of plastic bags, followed by Western Europe and then to the whole world (Clapp \& Swanston, 2009). At the start, it looked like users were unaware of its harmful effects (V \& HR, 2011), they continued its use as a comfortable and affordable material (Adane \& Muleta, 2011). Plastic production companies might be aware of the harmful 
environmental effects of plastic but like some of the other technological innovations (Mulder, 2013), nobody told the hazardous effects of this innovation until the substantial consequences were observed by the environmentalists and masses (Imran \& Abbas, 2020). People are used to it because of which it has become a challenge to stop the people from its use and provide them with some alternate options (Abbas, 2020a).

The profusion and limited tenure of plastic bags have tremendous harmful effects on the ecosystem of the world (Moharam \& Maqtari, 2014). Moreover, these products limited life span usage leads to disposal which take centuries for decomposition. More and more countries are in use of these products without the consideration of environmental impact (Kumar, 2018) as they are more concerned with current development instead of looking at the future consequences. No doubt there are several benefits associated with the use of plastic but the established system of plastic is now known for the severe environmental issues. So far, the concerned matter has been given less attention for its production and consumption patterns (Nielsen et al., 2019). Plastic bags' daily waste is the largest component of environment pollution. Food packs with plastic lining, plastic bottles and other such items' disposal can pollute groundwater and is also harmful to animal life. Because of careless attitude, $85 \%$ of plastic grocery bags are dumped in open landfills (Kumar, 2018). Some countries are yet formulating policies while some others have implemented rules and regulations against the use of polythene products. As per the United Nations (UN) 2018 report, it is mentioned that around 127 countries have implemented some kind of policies related to the prohibition for the use of plastic bags (Mahmood et al., 2014; Shah, 2019). Researchers, scholars, investigators and worldwide known national and international institutions have published several articles and reports on the harmful impact of plastic bags in different regions but unfortunately in Pakistan, the research related to the issue under consideration is very limited.

In Pakistan's scenario, recently it has been observed that the government has realized the severity of problems associated with the uncontrollable use of plastics. The restriction on the consumption of plastic items has been imposed in multiple cities in Pakistan. Although some of the shopkeepers have been charged heavy penalties for the violation of adopted policy (Baloch, 2019) currently the practice of use of plastic bags could not be stopped because of the negligence and uncontrollability of the concerned governmental authorities. Environment Protection Authority in Federal Capital and Departments in provinces are not playing their due role for effectively checking pollution and maintaining the environment clean and healthy.

The study has been conducted for identification of problems associated with the excessive usage of plastic bags from the public perspective. Public opinion on the issue is necessary to be taken to solve the problems for the protection of existing animals and plant species and their upcoming generations for the sustainability and continuity of the life cycle. In this era, it is necessary to access the severity of the problem, identify the reasons and provide alternative solutions regarding the hazardous and profound impact of plastic bags on our surroundings. The situation is worsening because these bags regular consumption is resulting in unrecoverable loss of productive land, clean water and fresh air that is essential for living beings. The data has been collected from the individuals irrespective of their gender, education, religion, background, caste, colour and profession. 


\section{Literature Review}

Plastic has come up with numerous benefits of being low-cost, ponderous, resilient, strong and durable with good insulation properties, providing benefits particularly in the health sector and other areas. Due to these advantages, the production of plastic bags increased significantly from 0.5 million tons in 1950 to 260 million tons in 2008. Packaging, electrical equipment and plastics from extinct vehicles are a major source of domestic and industrial wastes (Thompson et al., 2009). In the case of plastic bags, most of them are disposed of as waste after single time usage. It is stated that plastics can remain in the environment for 1000 years without decomposition from the sunlight, microorganisms or bacteria. The common problems associated with these bags are deterioration of the environment and direct or indirect threat to the life of a human as well as animals (Abbas, 2019). If the bags get buried in agriculture land, they reduce the percolation of water and passage of necessary air to the soil which results in the reduction of overall productivity of the land (Habib et al., 2019). Moreover, in poor and underdeveloped countries, plastics are commonly used for the packing and carriage of food products. This practice can cause complex health issues as several cancer-causing elements can be produced in chemical actions which occur in plastics and food items because of temperature differences (Adane \& Muleta, 2011).

Plastics remain in the environment for a long time because they are non-degradable. They are made from exhaustible resources; petroleum and natural gas are major components among them. Polythene of various densities is the basic materials commonly consumed for the production of plastics. Linear low-density polythene (LLDPE) is widely used for the manufacturing of shopping bags and commonly used in retail and superstores, to attain a preferred thickness, shiny and smooth look (Abbas, Muzaffar, Shoaib, et al., 2014). Plastic bags' disposal has a dangerous impact on soil and water due to the presence of toxic chemical substances. In Mumbai (city of India), plastic waste has become a major problem for the municipal authorities due to the littering practice and poor waste management system. Many of the plastic bags are failed to reach the recycling process because most of the times plastic bags are treated as domestic waste (Chaudhuri, 2016). Plastic wastes in large amount are difficult to finish in the world but we can take steps to come out of this problem by becoming more aware of the issue and initiating work on the reduction of waste. Regular use of plastic is among the major reasons for the increase in environmental degradation.

Plastic is also responsible for most of the pollution in the river and land as it has a horrific impact on both water and land species (Abbas \& Sagsan, 2019). This can result in a poor economy and inadequate food supply for societies that are dependent on fishing. Small organisms like plankton can be hurt by plastic that large animals eat for food. If these tiny organisms are poisoned by ingesting plastic; the large animals will also consume chemicals. This trend will go in the upward direction and the chances are there that these chemicals can be present in the fish which people eat. It is not only polluting the oceans but also the groundwater resources. Generally, many areas all over the world are facing major issues due to the use of plastic but the water resources across the globe are particularly in danger. Dumping and littering of plastic waste can result in seeping of plastic toxins into the groundwater which people drink regularly. On the land, deterioration of natural beauty can be observed. Moreover, wind can carry plastic waste or litter throughout the atmosphere (Kumar, 2018). 
In the process of plastic production, various harmful materials are produced to impact the environment. These materials contribute to acid rain which is the real threat to the natural and artificial environment especially in the regions which were historically highly dependent on coal, such as Eastern Europe. On the other hand, smog is also responsible for human health issues. Furthermore, two plastic shopping bags manufacturing produces $0.1 \mathrm{~kg}$ of waterborne waste that is capable of disrupting associated environment such as water channels and the life therein exist. The problem of air and water pollution is more intensified when it is found that most of the plastic shopping bags are manufactured in the countries having few eco-friendly regulations like China that comes up with adverse effect on the environment and human health (Ellis et al., 2005). These bags are not only causing air and water pollution but they have also made a negative impact on agriculture lands. Many individuals do not know reuse of plastic waste that pollutes the agriculture land and mixes with other decomposable materials. As plastics are nonbiodegradable, they remain in the soil and block the supply of minerals and water to the agriculture land, necessary for the growth of plants. Even though plastic bags have the characteristic of thin in size, it resists roots of crops to penetrate through the bags and move around the soil to find the nutrients. In this way, plastic bags are responsible for the immense harm to the agriculture land for the growth of agriculture plants and fields (M. A. J. Jalil \& Mian, 2011).

Plastic bags obstruct the sewerage system in populated areas and towns. Such a situation creates bad smells and becomes a source of various bacteria that could increase a large number of diseases (Adane \& Muleta, 2011). Still, in urban areas, where wildlife is relatively limited, plastic bags cause significant environmental harm. Runoff water collects and carries useless plastic bags and finally collects them into storm sewers. Once in these sewers, the bag often forms clumps with other types of wastes and ultimately block the flow of water (Abbas, 2020b). This prevents the run of water from properly draining, which often cause inconvenience to those living or working in the area. For example, roads often flood when storm sewers become blocked, which forces them to be closed until the water drains. This excess water can damage roads, buildings and other property. It also collects pollutants and spreads them far and wide, where they cause extra damage. Blocked storm sewers can also disrupt the water flow throughout local watersheds. Blocked gutter pipes can starve local wetlands, creeks and streams of the water they require, which can lead to massive die-offs and in some cases, total downfall. (Greener Ideal Staff, 2018).

Such problems are developed due to non-seriousness of peoples for disposing of litter including plastics and other items in open places. Some people burn plastic bags at roads or grounds that produce very harmful smoke fatal for health and increase environment temperature. It has been learnt that in Malaysia, the temperature is gradually but slowly increasing due to which sea level may rise and result in flash floods. To control such untoward situation, Malaysia restricted the use of plastics (Abbas \& Sagsan, 2019). Singapore, the neighbour of Malaysia has already banned the use of plastic bags to avoid the harmful effects of plastics on agriculture production and environment (Md. A. Jalil et al., 2013). In this regard, a study was carried out to find out the effects of the decrease in plastic bag usage in big markets (Ohtomo \& Ohnuma, 2014). The study was carried out by adopting a dual motivation model about the usage of plastic bags and it was evaluated that how environment-friendly behaviour affects actual behaviour of the individual (Abbas et al., 2015; Abbas, Muzaffar, Mahmood, et al., 
2014). In the first week, the shop keeper gave free plastic bags to purchasers in routine. In the second week, the intervening week, of study, customers were asked if they wanted to get plastic bags or otherwise. It was analysed that during the pre-intervention week (first week), 78\% of the customers accepted to receive plastic bags and $22 \%$ did not accept. In the post-intervention week (second week), $73 \%$ of the customers refused to accept plastic bags and only $27 \%$ accepted to receive plastic bags. A significant difference in acceptance of plastic bags was observed in pre and post-intervention week. This shows that the question asked by the shopkeeper helped in reducing the use of plastic bags. Therefore, it indicates that planned human efforts always help to achieve objectives. In this case, the objective was to reduce the usage of plastic bags because of their harmful effects.

Based on the above discussion, this research proposes the following hypotheses;

H1: Plastic bags are the most commonly used products.

H2: Characteristics of plastic bags are the reason behind its wide usage.

H3: There is no environment-friendly option for plastic bags disposal.

H4: Plastic bags are causing various environmental issues.

H5: Media has an important role in creating awareness about plastic bags harmful effects.

H6: There is an increasing trend in the usage of plastic bags.

H7: Plastic bags can be substituted with their alternative options.

\section{Conceptual Framework}

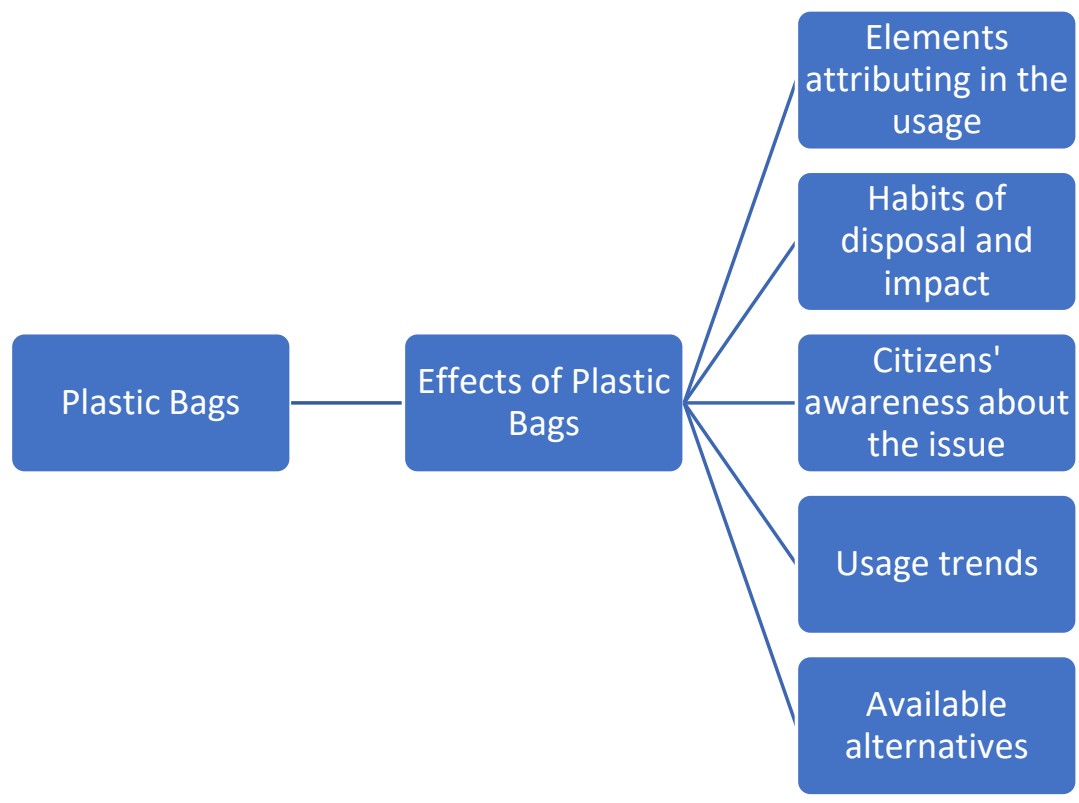

\section{Research Methodology}

Target Population

Data has been collected from Islamabad (capital of Pakistan) and Rawalpindi (city of the province, Punjab). Islamabad is located adjacent to Rawalpindi on the North-Eastern side of the Potohar plateau. Connection of border of these two cities is the major reason behind naming it as twin cities. The region is at the altitude ranging from 457 to 610 meters above the sea level. It is one of the highest rainfall areas in the country with an average of 1143 millimetres because of this reason; the area humidity is 55\% (Capital Development Authority, 2020). The ideal target 
population is from Pakistan where according to the year 2017 census, 207.774 million people are living. In 2017, the total human population of the twin cities was estimated at 7.407 million in which 2.002 million lives in Islamabad and 5.406 million in Rawalpindi (Pakistan Bureau of Statistics, 2020). Most of the public living in the region can read and write. In general, public living in the constituency is students, households, government and private sector job holders and businessmen.

\section{Sampling Techniques, Data Collection and Analysis}

Information was gathered from 173 respondents comprised of 131 males and 42 females. The investigation subjects were chosen using a non-probability convenience sampling technique. The respondents were selected from universities' students, business centres, family units that were from different places of twin-city. Among the visited families, in any event, a single individual from the family was randomly selected for the examination irrespective of their age, educational status and sex as long they were willing to respond. The number of males was higher than females because males demonstrated more willingness to meet and fill the given polls. On the other side, the majority of the females were unwilling, when we asked them to fill the forms. To gather the information, survey questionnaires and google forms were distributed among the residents of the targeted region. Format and all the questions asked in the questionnaire were set in English for the convenience of citizens. The questionnaire was selected from the research article. The measurement instrument to conduct the study was extracted from the research article by Adane and Muleta (2011). Format of the research and data collection is similar to the case study mentioned earlier. Before the collection of responses, discussions were held with the chosen respondents to clarify the goal of the study. Those respondents who were willing but unable to respond to the questionnaires by themselves were assisted by the researchers of this article. It was assured that each point was explained to them clearly so that they could fill the form responsibly and with due care of the society. For segregating the gathered information, the respondents were assembled into various classes.

Most of the respondents were students (81.50\%), the reason behind an excessive number of students in the collection of data was their willingness to fill the forms because they understand what we are doing and how to fill the form and they know the importance of the data. At the second numbers were private businessmen (19.07\%) and the others were government servants (6.93\%). The age of most of the respondents was $20-29$ (57.22\%) because as we already discussed in the previous paragraph that the majority of the respondents were students. At the second number were respondents of less than 20 years of age (26.58\%), 30-29 years' age group was at the third position (12.13\%) and in the last, minimum number of respondents were of 40 plus year (4.04\%). In the last, we discuss our respondents' educational status. A large number of our respondents were highly educated and graduate or undergraduate students (61.84\%), high school students were at second position among respondents (30.63\%), then that of primary education (5.20\%) and in the last, the number of illiterate was very low (2.31\%) who never studied in their entire life (See Table-1). 
INTERNATIONAL JOURNAL OF ACADEMIC RESEARCH IN BUSINESS AND SOCIAL SCIENCES

Vol. 10, No. 10, 2020, E-ISSN: 2222-6990 @ 2020 HRMARS

Data Analysis, Results and Discussion

Table 1: Demographics data of respondents (Islamabad and Rawalpindi)

\begin{tabular}{|l|l|r|r|}
\hline \multicolumn{1}{|c|}{ Variables } & \multicolumn{1}{|c|}{ Categories } & No. & Percentage \\
\hline Sex & Male & 131 & $75.72 \%$ \\
& Female & 42 & $24.28 \%$ \\
\hline Age & $<20$ years & 46 & $26.59 \%$ \\
& $20-29$ years & 99 & $57.22 \%$ \\
& $30-39$ years & 21 & $12.14 \%$ \\
& $\geq 40$ years & 7 & $4.05 \%$ \\
\hline Educational Status & Illiterate & 4 & $2.31 \%$ \\
& Primary Education & 9 & $5.20 \%$ \\
& High School & 53 & $30.64 \%$ \\
& Higher Education & 107 & $61.85 \%$ \\
\hline Occupation & Students & 114 & $65.90 \%$ \\
& Government & 12 & $6.94 \%$ \\
& Employees & 33 & $19.08 \%$ \\
& Private & 14 & $8.09 \%$ \\
\hline
\end{tabular}

\section{Elements Behind the Increasing Trend of using Plastic Bags}

Out of 173 respondents, the majority of the people use plastic bags in large quantities as compared to other plastic items. The data indicates the usage of plastic bags by males is $56.49 \%$, plastic bottles $19.08 \%$, plastic buckets, barrels and baskets $17.56 \%$, plastic shoes $5.34 \%$. On the other hand, the usage of plastic bags by females is $42.86 \%$, plastic bottles $21.43 \%$, plastic buckets, barrels and baskets $28.57 \%$, plastic shoes $7.14 \%$. This data indicates that most of the respondents in all the given categories use plastic bags in their daily life. This data indicates that plastic bags are used highly among the residents of twin cities, and the residents say that they have been observing excessive use of plastic bags concerning time. All these results indicate that plastic bags are also excessively used product in the twin cities (See Table-2). 
INTERNATIONAL JOURNAL OF ACADEMIC RESEARCH IN BUSINESS AND SOCIAL SCIENCES

Vol. 10, No. 10, 2020, E-ISSN: 2222-6990 @ 2020 HRMARS

Table 2: Plastic Products

\begin{tabular}{|c|c|c|c|c|c|c|c|c|c|c|}
\hline \multirow[t]{2}{*}{ Variables } & \multicolumn{2}{|c|}{ Plastic bags } & \multicolumn{2}{|c|}{$\begin{array}{l}\text { Plastic } \\
\text { bottles }\end{array}$} & \multicolumn{2}{|c|}{$\begin{array}{c}\text { Plastic } \\
\text { buckets, } \\
\text { barrels and } \\
\text { baskets }\end{array}$} & \multicolumn{2}{|c|}{ Plastic Shoes } & \multicolumn{2}{|c|}{ Others } \\
\hline & No. & $\%$ & No. & $\%$ & No. & $\%$ & No. & $\%$ & No. & $\%$ \\
\hline Sex & & & & & & & & & & \\
\hline Male & 74 & $56.49 \%$ & 25 & $19.08 \%$ & 23 & $17.56 \%$ & 7 & $5.34 \%$ & 2 & $1.53 \%$ \\
\hline Female & 18 & $42.86 \%$ & 9 & $21.43 \%$ & 12 & $28.57 \%$ & 3 & $7.14 \%$ & 0 & $0 \%$ \\
\hline $\begin{array}{l}\text { Educational } \\
\text { Status } \\
\text { Illiterate }\end{array}$ & & & & & & & & & & \\
\hline Primary & 1 & $25 \%$ & 0 & $0 \%$ & 3 & $75 \%$ & 0 & $0 \%$ & 0 & $0 \%$ \\
\hline Education & 1 & $11.11 \%$ & 2 & $22.22 \%$ & 5 & $55.56 \%$ & 1 & $11.11 \%$ & 0 & $0 \%$ \\
\hline High School & 25 & $47.17 \%$ & 9 & $16.98 \%$ & 14 & $26.41 \%$ & 5 & $9.43 \%$ & 0 & $0 \%$ \\
\hline $\begin{array}{l}\text { Education } \\
\text { Higher } \\
\text { Education }\end{array}$ & 65 & $60.75 \%$ & 23 & $21.50 \%$ & 13 & $12.15 \%$ & 4 & $3.74 \%$ & 2 & $1.87 \%$ \\
\hline Age Group & & & & & & & & & & \\
\hline$<20$ years & 27 & $58.70 \%$ & 8 & $17.39 \%$ & 8 & $17.39 \%$ & 3 & $6.52 \%$ & 0 & $0 \%$ \\
\hline $20-29$ years & 56 & $56.57 \%$ & 22 & $22.22 \%$ & 18 & $18.18 \%$ & 2 & $2.02 \%$ & 1 & $1.01 \%$ \\
\hline $30-39$ years & 6 & $28.57 \%$ & 4 & $19.05 \%$ & 7 & $33.33 \%$ & 3 & $14.29 \%$ & 1 & $4.76 \%$ \\
\hline$\geq 40$ years & 3 & $42.86 \%$ & 0 & $0 \%$ & 2 & $28.57 \%$ & 2 & $28.57 \%$ & 0 & $0 \%$ \\
\hline Occupation & & & & & & & & & & \\
\hline Student & 66 & $57.89 \%$ & 25 & $21.93 \%$ & 20 & $17.54 \%$ & 2 & $1.75 \%$ & 1 & $0.88 \%$ \\
\hline Gov't Employee & 3 & $25 \%$ & 4 & $33.33 \%$ & 4 & $33.33 \%$ & 1 & $8.33 \%$ & 0 & $0 \%$ \\
\hline Private & 14 & $42.42 \%$ & 3 & $9.09 \%$ & 9 & $27.27 \%$ & 7 & $21.21 \%$ & 0 & $0 \%$ \\
\hline Others & 9 & $64.29 \%$ & 2 & $14.29 \%$ & 2 & $14.29 \%$ & 0 & $0 \%$ & 1 & $7.14 \%$ \\
\hline
\end{tabular}

This survey result shows that irrespective of gender, education, occupation and age, 53\% of the peoples of Islamabad and Rawalpindi extensively use plastic bags in their routine life activities. A portion of the primary widespread usage was the low price (16.76\%), light in weight (25.43\%), easy to find (33.52\%) and lack of alternative materials (24.28\%). These discoveries are matching with other reports portraying that light-weight, modest cost, phenomenal qualification for use and asset effectiveness are fundamental reasons for over usage of plastic bags all over the world. During our research, we observed that all the shopkeepers, stores, malls and all kinds of different stores give these plastic bags free of cost to their customers whenever they buy something from their stores. This indicates that ease of use and free dispersion of these materials by retailers or store proprietors are the main reason behind the wide usage of plastic bags. For example, our survey in Islamabad \& Rawalpindi indicates that $53 \%$ of customers of markets and 
superstores use free plastic bags. Moreover, it has also been observed that educated people take more interest in plastic bags over other options.

\section{Practices of Plastic Bag Wastes Removal and their Ecological Effects}

After onetime use, plastic bags have to be disposed of. In this way, additional data were collected from respondents about the ways how they dispose of plastic bag wastes. The data about throwing in open areas (46.82\%) and burning $(30.63 \%)$ is the norm of disposal of plastic bag wastes. Open dumping to the nearby areas is done by most of the peoples. This indicates that "dumping" at open places is the common practice of peoples of the twin cities. Of the 173 respondents, just 27 (15.60\%) and 12 (16.13\%) of them used burying and another kind of methods to dispose of the waste, respectively. The majority of these respondents $(81,46.82 \%)$ utilized open dumping. Our survey questionnaires and google forms observations show that plastic bag wastes constituted a larger share of plastic wastes in the twin cities and its adjoining areas. As shown in our table, burning is also a commonly used method. Female respondents who throw the wastes to the environment were slightly larger in number $(21,50 \%)$ as compared to those females who burn $(10,23.81 \%)$ plastic bag wastes. It is expected that educated members of society are more concerned about the environment but the results of our survey show that these educated members of society appeared to be less worried about the environment. Therefore, all people from society need to make the effort for making the earth free of plastic bags. Because of this bag wastes, our environment is deteriorating rapidly.

Table 3: Factors attributed to widespread utilization of plastic bags

\begin{tabular}{|c|c|c|c|c|c|c|c|c|c|c|}
\hline \multirow[t]{2}{*}{ Variables/Category } & \multicolumn{2}{|c|}{ Low Price } & \multicolumn{2}{|c|}{$\begin{array}{l}\text { Light in } \\
\text { Weight }\end{array}$} & \multicolumn{2}{|c|}{$\begin{array}{c}\text { Easy } \\
\text { Availability }\end{array}$} & \multicolumn{2}{|c|}{$\begin{array}{c}\text { Lack of } \\
\text { Alternative } \\
\text { materials }\end{array}$} & \multicolumn{2}{|c|}{ Others } \\
\hline & No. & $\%$ & No. & $\%$ & No. & $\%$ & No. & $\%$ & No. & $\%$ \\
\hline $\begin{array}{l}\text { Sex } \\
\text { Male }\end{array}$ & 25 & $19.08 \%$ & 34 & 25.95 & 39 & $29.77 \%$ & 33 & $25.19 \%$ & 0 & $0 \%$ \\
\hline Female & 4 & $9.52 \%$ & 10 & 23.81 & 19 & $45.24 \%$ & 9 & $21.43 \%$ & 0 & $0 \%$ \\
\hline $\begin{array}{l}\text { Educational Status } \\
\text { Illiterate } \\
\text { Primary Education } \\
\text { High School } \\
\text { Education } \\
\text { Higher Education }\end{array}$ & $\begin{array}{r}4 \\
2 \\
8 \\
15\end{array}$ & $\begin{array}{r}100 \% \\
22.22 \% \\
15.09 \% \\
14.02 \%\end{array}$ & $\begin{array}{r}0 \\
2 \\
17 \\
25\end{array}$ & $\begin{array}{r}0 \\
22.22 \\
32.07 \\
23.36\end{array}$ & $\begin{array}{r}0 \\
3 \\
19 \\
36\end{array}$ & $\begin{array}{r}0 \% \\
33.33 \% \\
35.85 \% \\
33.64 \%\end{array}$ & $\begin{array}{r}0 \\
2 \\
9 \\
31\end{array}$ & $\begin{array}{r}0 \% \\
22.22 \% \\
16.98 \% \\
28.97 \%\end{array}$ & $\begin{array}{l}0 \\
0 \\
0 \\
0\end{array}$ & $\begin{array}{l}0 \% \\
0 \% \\
0 \% \\
0 \%\end{array}$ \\
\hline $\begin{array}{l}\text { Age Group } \\
<20 \text { years } \\
20-29 \text { years } \\
30-39 \text { years } \\
\geq 40 \text { years }\end{array}$ & $\begin{array}{r}11 \\
12 \\
3 \\
3\end{array}$ & $\begin{array}{l}23.91 \% \\
12.12 \% \\
14.29 \% \\
42.86 \%\end{array}$ & $\begin{array}{r}13 \\
27 \\
3 \\
1\end{array}$ & $\begin{array}{l}28.26 \\
27.27 \\
14.29 \\
14.29\end{array}$ & $\begin{array}{r}14 \\
33 \\
10 \\
1\end{array}$ & $\begin{array}{l}30.43 \% \\
33.33 \% \\
47.62 \% \\
14.29 \%\end{array}$ & $\begin{array}{r}8 \\
27 \\
5 \\
2\end{array}$ & $\begin{array}{l}17.39 \% \\
27.27 \% \\
23.81 \% \\
28.57 \%\end{array}$ & $\begin{array}{l}0 \\
0 \\
0 \\
0\end{array}$ & $\begin{array}{l}0 \% \\
0 \% \\
0 \% \\
0 \%\end{array}$ \\
\hline $\begin{array}{l}\text { Occupation } \\
\text { Student } \\
\text { Gov't Employee } \\
\text { Private } \\
\text { Others } \\
\end{array}$ & $\begin{array}{r}19 \\
0 \\
9 \\
1\end{array}$ & $\begin{array}{r}16.67 \% \\
0 \% \\
27.27 \% \\
7.14 \% \\
\end{array}$ & $\begin{array}{r}30 \\
6 \\
5 \\
3\end{array}$ & $\begin{array}{r}26.32 \% \\
50 \% \\
15.15 \% \\
21.43 \%\end{array}$ & $\begin{array}{r}32 \\
4 \\
16 \\
6\end{array}$ & $\begin{array}{l}28.07 \% \\
33.33 \% \\
48.48 \% \\
42.86 \%\end{array}$ & $\begin{array}{r}32 \\
2 \\
3 \\
4\end{array}$ & $\begin{array}{r}28.95 \% \\
16.67 \% \\
9.09 \% \\
28.57 \% \\
\end{array}$ & $\begin{array}{l}0 \\
0 \\
0 \\
0\end{array}$ & $\begin{array}{l}0 \% \\
0 \% \\
0 \% \\
0 \%\end{array}$ \\
\hline
\end{tabular}


INTERNATIONAL JOURNAL OF ACADEMIC RESEARCH IN BUSINESS AND SOCIAL SCIENCES

Vol. 10, No. 10, 2020, E-ISSN: 2222-6990 @ 2020 HRMARS

Table 4: Plastic bag waste disposal

\begin{tabular}{|c|c|c|c|c|c|c|c|c|}
\hline \multirow[t]{2}{*}{ Variables/Category } & \multicolumn{2}{|c|}{$\begin{array}{c}\text { Open } \\
\text { Dumping }\end{array}$} & \multicolumn{2}{|c|}{ Burying } & \multicolumn{2}{|c|}{ Burning } & \multicolumn{2}{|c|}{ Others } \\
\hline & No. & $\%$ & No. & $\%$ & No. & $\%$ & No. & $\%$ \\
\hline \multicolumn{9}{|l|}{ Sex } \\
\hline Male & 60 & $45.80 \%$ & 18 & $13.74 \%$ & 43 & $32.82 \%$ & 10 & $7.63 \%$ \\
\hline Female & 21 & $50 \%$ & 9 & $21.43 \%$ & 10 & $23.81 \%$ & 2 & $4.76 \%$ \\
\hline \multicolumn{9}{|l|}{ Educational Status } \\
\hline Illiterate & 2 & $50 \%$ & 2 & $50 \%$ & 0 & $0 \%$ & 0 & $0 \%$ \\
\hline Primary Education & 5 & $55.56 \%$ & 0 & $0 \%$ & 3 & $33.33 \%$ & 1 & $11.11 \%$ \\
\hline High School & 21 & $39.62 \%$ & 10 & $18.87 \%$ & 21 & $39.62 \%$ & 1 & $1.89 \%$ \\
\hline Higher Education & 53 & $49.53 \%$ & 15 & $14.02 \%$ & 29 & $27.10 \%$ & 10 & $9.35 \%$ \\
\hline \multicolumn{9}{|l|}{ Age Group } \\
\hline$<20$ years & 19 & $41.30 \%$ & 4 & $8.70 \%$ & 17 & $36.96 \%$ & 6 & $13.04 \%$ \\
\hline $20-29$ years & 48 & $48.48 \%$ & 18 & $18.18 \%$ & 27 & $27.27 \%$ & 6 & $6.06 \%$ \\
\hline 30-39 years & 9 & $42.86 \%$ & 4 & $19.05 \%$ & 8 & $38.09 \%$ & 0 & $0 \%$ \\
\hline$\geq 40$ years & 5 & $71.43 \%$ & 1 & $14.29 \%$ & 1 & $14.29 \%$ & 0 & $0 \%$ \\
\hline \multicolumn{9}{|l|}{ Occupation } \\
\hline Student & 50 & $43.86 \%$ & 18 & $15.79 \%$ & 37 & $32.46 \%$ & 9 & $7.89 \%$ \\
\hline Gov't Employee & 6 & $50 \%$ & 2 & $16.67 \%$ & 4 & $33.33 \%$ & 0 & $0 \%$ \\
\hline Private & 17 & $51.51 \%$ & 5 & $15.15 \%$ & 9 & $27.27 \%$ & 2 & $6.06 \%$ \\
\hline Others & 8 & $57.14 \%$ & 2 & $14.29 \%$ & 3 & $21.43 \%$ & 1 & $7.14 \%$ \\
\hline
\end{tabular}

In our survey, we have found that there are a few issues related to plastic bag wastes in twin cities. The information shown in table demonstrated that animal death $(20,11.56 \%)$, sewage choking frameworks $(45,26.01 \%)$, the decay of natural beauty of environment due to littering $(25,14.45 \%)$ and human health problems $(29,16.76 \%)$ were the main issues about which respondents were worried about. The outcome of the present survey demonstrates that most of the respondents, irrespective of their background, express the issues of plastic bag wastes on creatures. These realities and results of the present analysis recommend the requirement for quick action to launch an awareness campaign about the harmful effects of plastic bag wastes on the health of living organisms including human as well as animals. The spots with the high aggregation of plastic bag wastes include parks (15, 9.25\%), waste dumping sites $(18,10.40 \%)$, market places $(18,10.40 \%)$ and crowded residential areas $(23,13.29 \%)$ not mentioned in the table. Other areas that were less polluted as compared to preceding areas are roadsides (2, $1.15 \%)$, open places in the city $(4,2.30 \%)$ and sewage lines $(7,4.05 \%)$. These data show that the environmental pollution brought by plastic bag wastes is a great concern in the twin cities. As it was told earlier, plastic bags are not decomposed and remain for 100 of years, if they remain in enormous amounts in soil, they forestall air and water dissemination that results into a decrease in the productivity of farmlands. During our field visits, it was seen that the district government 
INTERNATIONAL JOURNAL OF ACADEMIC RESEARCH IN BUSINESS AND SOCIAL SCIENCES

Vol. 10, No. 10, 2020, E-ISSN: 2222-6990 @ 2020 HRMARS

put of strong plastic waste close to the residential areas that exist inside the city demonstrating the triviality of the management.

Table 5: Problems associated with plastic bag wastes

\begin{tabular}{|c|c|c|c|c|c|c|c|c|c|c|}
\hline \multirow[t]{2}{*}{ Variables/Category } & \multicolumn{2}{|c|}{$\begin{array}{l}\text { Animal } \\
\text { death }\end{array}$} & \multicolumn{2}{|c|}{$\begin{array}{l}\text { Human } \\
\text { health } \\
\text { problem }\end{array}$} & \multicolumn{2}{|c|}{$\begin{array}{c}\text { Blockage of } \\
\text { sewage }\end{array}$} & \multicolumn{2}{|c|}{$\begin{array}{c}\text { Deterioration } \\
\text { of natural } \\
\text { beauty }\end{array}$} & \multicolumn{2}{|c|}{ Others } \\
\hline & No. & $\%$ & No. & $\%$ & No. & $\%$ & No. & $\%$ & No. & $\%$ \\
\hline $\begin{array}{l}\text { Sex } \\
\text { Male }\end{array}$ & 16 & $16.84 \%$ & 24 & $25.26 \%$ & 33 & $34.74 \%$ & 18 & $18.95 \%$ & 4 & $4.2 \%$ \\
\hline Female & 4 & $13.33 \%$ & 5 & $16.67 \%$ & 12 & $40 \%$ & 7 & $23.33 \%$ & 2 & $6.67 \%$ \\
\hline $\begin{array}{l}\text { Educational Status } \\
\text { Illiterate } \\
\text { Primary Education } \\
\text { High School } \\
\text { Education } \\
\text { Higher Education }\end{array}$ & $\begin{array}{r}1 \\
0 \\
6 \\
13\end{array}$ & $\begin{array}{r}100 \% \\
0 \% \\
20.69 \% \\
14.13 \%\end{array}$ & $\begin{array}{r}0 \\
0 \\
7 \\
22\end{array}$ & $\begin{array}{r}0 \% \\
0 \% \\
24.14 \% \\
23.91 \%\end{array}$ & $\begin{array}{r}0 \\
3 \\
11 \\
31\end{array}$ & $\begin{array}{r}0 \% \\
100 \% \\
37.93 \% \\
33.70 \%\end{array}$ & $\begin{array}{r}0 \\
0 \\
4 \\
21\end{array}$ & $\begin{array}{r}0 \% \\
0 \% \\
13.79 \% \\
22.83 \%\end{array}$ & $\begin{array}{l}0 \\
0 \\
1 \\
5\end{array}$ & $\begin{array}{r}0 \% \\
0 \% \\
3.45 \% \\
5.43 \%\end{array}$ \\
\hline $\begin{array}{l}\text { Age Group } \\
<20 \text { years } \\
20-29 \text { years } \\
30-39 \text { years } \\
\geq 40 \text { years }\end{array}$ & $\begin{array}{r}3 \\
14 \\
2 \\
1 \\
\end{array}$ & $\begin{array}{r}9.68 \% \\
17.07 \% \\
28.57 \% \\
20 \% \\
\end{array}$ & $\begin{array}{r}8 \\
19 \\
2 \\
0\end{array}$ & $\begin{array}{r}25.81 \% \\
23.17 \% \\
28.57 \% \\
0 \% \\
\end{array}$ & $\begin{array}{r}15 \\
26 \\
2 \\
2\end{array}$ & $\begin{array}{r}48.39 \% \\
31.71 \% \\
28.57 \% \\
40 \% \\
\end{array}$ & $\begin{array}{r}3 \\
19 \\
1 \\
2 \\
\end{array}$ & $\begin{array}{r}9.68 \% \\
23.17 \% \\
14.29 \% \\
40 \% \\
\end{array}$ & $\begin{array}{l}2 \\
4 \\
0 \\
0\end{array}$ & $\begin{array}{r}6.45 \% \\
4.88 \% \\
0 \% \\
0 \% \\
\end{array}$ \\
\hline $\begin{array}{l}\text { Occupation } \\
\text { Student } \\
\text { Gov't Employee } \\
\text { Private } \\
\text { Others }\end{array}$ & $\begin{array}{r}15 \\
2 \\
2 \\
1\end{array}$ & $\begin{array}{r}15.96 \% \\
33.33 \% \\
14.29 \% \\
9.09 \%\end{array}$ & $\begin{array}{r}24 \\
1 \\
3 \\
1\end{array}$ & $\begin{array}{r}25.53 \% \\
16.67 \% \\
21.43 \% \\
9.09 \%\end{array}$ & $\begin{array}{r}31 \\
2 \\
5 \\
7\end{array}$ & $\begin{array}{l}32.98 \% \\
33.33 \% \\
35.71 \% \\
63.64 \%\end{array}$ & $\begin{array}{r}19 \\
1 \\
4 \\
1\end{array}$ & $\begin{array}{r}20.21 \% \\
16.67 \% \\
28.57 \% \\
9.09 \%\end{array}$ & $\begin{array}{l}5 \\
0 \\
0 \\
1\end{array}$ & $\begin{array}{r}5.32 \% \\
0 \% \\
0 \% \\
9.09 \%\end{array}$ \\
\hline
\end{tabular}

\section{Role of media in highlighting the issue among citizens}

Most of the respondents $(53,30.63 \%)$ valued the significant roles of TV and Radio in the sharing of data about the unfavourable effects of plastic bag wastes. A different source of data that was collected includes health experts $(20,11.56 \%)$, schools $(12,6.93 \%)$ and distributed materials $(26,15.02 \%)$. The outcome in the table recommends that it is conceivable to utilize this media to educate peoples regarding issues caused by plastic bag wastes. Although not evaluated, it has been observed that the majority of the people have access to media. In this manner, the teaching of the community through the media is easy for better comprehension of the negative impacts of plastic bags. Other things that are impacting highly in building perception and creating awareness among people is social media. In our studies, some people also said that they got awareness also from social media. In the table, it appears that just (44, 19.13\%) of the respondents get data from papers and magazines. This could be ascribed to the absence of these materials having inclusion on these squanders. This reality was steady with the creators' overview 
of some well-known magazines and papers available in the twin-city. No data were available concerning the effects of plastic bags on nature.

Similarly, the data demonstrates that the new-born generation must be educated at primary education level regarding the protection of the environment from toxic elements. Likewise, the organizations must develop a culture for saving the green environment. The minimum use of plastic bags at schools and organizations would help reduce the pollution impact on the environment. The level of awareness must be enhanced to curtail the usage of plastic bags. The government functionaries must play their role as a model for others.

The dominant part of the respondents in each category has great knowledge about the issues related to plastic bag wastes. This recommends that it will need a little effort to prepare the twin-city residents to make a move against the disposal and usage of plastic bags. However, too much has to be done to change the habit of plastic bags usage.

Table 5: Information about plastic bag wastes

\begin{tabular}{|c|c|c|c|c|c|c|c|c|c|c|}
\hline \multirow[t]{2}{*}{ Variables/Category } & \multicolumn{2}{|c|}{ TV/Radio } & \multicolumn{2}{|c|}{ School } & \multicolumn{2}{|c|}{ Professionals } & \multicolumn{2}{|c|}{$\begin{array}{l}\text { Published } \\
\text { Materials }\end{array}$} & \multicolumn{2}{|c|}{ Others } \\
\hline & No. & $\%$ & No. & $\%$ & No. & $\%$ & No. & $\%$ & No. & $\%$ \\
\hline Sex & & & & & & & & & & \\
\hline Male & 43 & $48.86 \%$ & 7 & $7.95 \%$ & 17 & $19.32 \%$ & 18 & $20.45 \%$ & 3 & $3.41 \%$ \\
\hline Female & 10 & $35.71 \%$ & 5 & $17.86 \%$ & 3 & $10.71 \%$ & 8 & $28.57 \%$ & 2 & $7.14 \%$ \\
\hline $\begin{array}{l}\text { Educational Status } \\
\text { lliterate }\end{array}$ & 2 & $100 \%$ & 0 & $0 \%$ & 0 & $0 \%$ & & $0 \%$ & 0 & $0 \%$ \\
\hline Primary Education & 1 & $50 \%$ & 0 & $0 \%$ & 1 & $50 \%$ & 0 & $0 \%$ & 0 & $0 \%$ \\
\hline High School & 14 & $48.28 \%$ & 5 & $17.24 \%$ & 4 & $13.79 \%$ & 0 & $20.69 \%$ & 0 & $0 \%$ \\
\hline $\begin{array}{l}\text { Education } \\
\text { Higher Education }\end{array}$ & 36 & $43.37 \%$ & 7 & $8.43 \%$ & 15 & $18.07 \%$ & $\begin{array}{r}6 \\
20\end{array}$ & $24.10 \%$ & 5 & $6.02 \%$ \\
\hline Age Group & & & & & & & & & & \\
\hline$<20$ years & 13 & $43.33 \%$ & 4 & $13.33 \%$ & 3 & $10 \%$ & 9 & $30 \%$ & 1 & $3.33 \%$ \\
\hline $20-29$ years & 35 & $45.45 \%$ & 7 & $9.09 \%$ & 15 & $19.48 \%$ & 17 & $22.08 \%$ & 3 & $3.90 \%$ \\
\hline $30-39$ years & 3 & $42.86 \%$ & 1 & $14.29 \%$ & 2 & $28.57 \%$ & 0 & $0 \%$ & 1 & $14.29 \%$ \\
\hline$\geq 40$ years & 2 & $100 \%$ & 0 & $0 \%$ & 0 & $0 \%$ & 0 & $0 \%$ & 0 & $0 \%$ \\
\hline Occupation & & & & & & & & & & \\
\hline Student & 39 & $44.83 \%$ & 7 & $8.04 \%$ & 14 & $16.09 \%$ & 23 & $26.44 \%$ & 4 & $4.60 \%$ \\
\hline Gov't Employee & 1 & $16.67 \%$ & 3 & $50 \%$ & 2 & $33.33 \%$ & 0 & $0 \%$ & 0 & $0 \%$ \\
\hline Private & 4 & $33.33 \%$ & 2 & $16.67 \%$ & 4 & $33.33 \%$ & 2 & $16.67 \%$ & 0 & $0 \%$ \\
\hline Others & 9 & $81.82 \%$ & 0 & $0 \%$ & 0 & $0 \%$ & 1 & $9.09 \%$ & 1 & $9.09 \%$ \\
\hline
\end{tabular}

\section{Factors responsible for increasing or decreasing trend}

We also gathered data from our respondents about the increasing or decreasing trend of plastic bag usage and-coincidentally the result came from was $50 \%$ as half of our respondents are saying that they saw the increasing trend of utilization of plastic bags and other half were saying that they saw the decreasing trend in the utilization of plastic bags. So we are also discussing their reasons for increasing or decreasing trend in the usage of plastic bags. 
In the increasing trend section our respondents said that they saw a huge increasing trend in the utilization of plastic bags and the majority of the respondents said the reason was that plastic bag was very cheap $(31,27.62 \%)$ and easy in access $(23,13.29 \%)$. Shockingly, just about $15 \%$ of the respondents referred to "lack of awareness" as an essential reason behind the increasing trend in plastic bags utilization.

It has been observed in the survey that easy availability of plastic bags on cheap rates is also causing an increase in the usage which can be curtailed by strict policing and rules on the manufacturing industry.

Table 6: Factors responsible for the increasing trend

\begin{tabular}{|l|r|r|r|r|}
\hline \multirow{2}{*}{ Variables/Category } & \multicolumn{2}{|c|}{ Low Cost } & \multicolumn{2}{c|}{ Easy Access } \\
\cline { 2 - 5 } Sex & No. & \multicolumn{1}{|c|}{$\%$} & No. & \\
Male & 23 & $35.94 \%$ & 15 & $23.44 \%$ \\
Female & 8 & $38.09 \%$ & 8 & $38.09 \%$ \\
\hline Educational Status & & & & \\
Illiterate & 2 & $66.67 \%$ & 0 & $0 \%$ \\
Primary Education & 1 & $25 \%$ & 1 & $25 \%$ \\
High School Education & 7 & $35 \%$ & 3 & $15 \%$ \\
Higher Education & 21 & $36.21 \%$ & 19 & $32.76 \%$ \\
\hline Age Group & & & & \\
$<20$ years & 15 & $57.69 \%$ & 3 & $11.54 \%$ \\
20-29 years & 10 & $22.22 \%$ & 18 & $40 \%$ \\
30-39 years & 4 & $33.33 \%$ & 2 & $16.67 \%$ \\
$\geq 40$ years & 2 & $100 \%$ & 0 & $0 \%$ \\
\hline Occupation & & & & \\
Student & 19 & $33.33 \%$ & 15 & $26.32 \%$ \\
Gov't Employee & 10 & $40 \%$ & 1 & $20 \%$ \\
Private & 0 & $62.50 \%$ & 3 & $18.75 \%$ \\
Others & & $0 \%$ & 4 & $57.14 \%$ \\
\hline
\end{tabular}

Whereas in decreasing trend section respondents said that they had seen the decreasing trend in the utilization of plastic bags and the major factor involved in it was the awareness in the community about the harmful effects of plastic bags in the environment and how it had affected the eco-system in different ways. The respondents also said that the reason for the decreasing of plastic bag trends was that they now could easily get another kind of bags which were alternative to plastic bags. They said that the major factor was the restrictions from the government because the government took strict action against the shop keepers in the twin-city who were providing plastic bags to their customers. 
INTERNATIONAL JOURNAL OF ACADEMIC RESEARCH IN BUSINESS AND SOCIAL SCIENCES

Vol. 10, No. 10, 2020, E-ISSN: 2222-6990 @ 2020 HRMARS

Table 7: Factors responsible for decreasing trend

\begin{tabular}{|l|r|r|}
\hline \multirow{2}{*}{ Variables/Category } & \multicolumn{2}{|c|}{ Awareness of the community } \\
\cline { 2 - 3 } Sex & Nor & \multicolumn{1}{|c|}{$\%$} \\
Male & 35 & $50 \%$ \\
Female & 8 & $38.09 \%$ \\
\hline Educational Status & & \\
Illiterate & 0 & $0 \%$ \\
Primary Education & 1 & $20 \%$ \\
High School Education & 15 & $48.39 \%$ \\
Higher Education & 27 & $56.25 \%$ \\
\hline Age Group & & \\
$<20$ years & 5 & $27.78 \%$ \\
20-29 years & 30 & $56.60 \%$ \\
30-39 years & 6 & $66.67 \%$ \\
$\geq 40$ years & 2 & $40 \%$ \\
\hline Occupation & & \\
Student & 30 & $53.57 \%$ \\
Gov't Employee & 2 & $28.57 \%$ \\
Private & 8 & $50 \%$ \\
Others & 3 & $50 \%$ \\
\hline
\end{tabular}

\section{Alternatives to the plastic bags}

In the last, we asked questions about the solution of plastic bag alternative and (87, $50.28 \%$ ) of the people responded that the best alternative for the plastic bag was cloth bags because cloth bags were reusable. In respondents' opinion, it is the responsibility of all the shops, retailers and malls that they should provide cloth bags to their customers instead of plastic bags so they will not use plastic bags in their daily life use. The respondents also say that the habit of plastic bags using came from these shops because from the beginning whenever they buy anything they get a free plastic bag with it. The second most popular answer from our respondents was about paper bags. They tell that it is also the worthy alternative to plastic bags and it is also cheap not as much like plastic bags but it is and a suitable option. They said the big problem with these paper bags was that they were of very low quality and most of the time the paper bags got cracked but still it was the opt able alternative of plastic bags. The third most popular alternative to plastic bag according to our respondents is fibre bags. Environmentfriendly fibre bags are made from a kind of paper that has cotton strands to invigorate it with added pliable to help forestall tearing or extending. These creative and stylish bags are $100 \%$ biodegradable. Some of our respondents suggest the usage of fibre bags for their daily life use. In their opinion, these are the most popular alternative and these kinds of alternatives should come to market so that we can get rid of plastic bags. From this study, we realize that some stern actions need to be taken to make our environment a plastic bag free. 
INTERNATIONAL JOURNAL OF ACADEMIC RESEARCH IN BUSINESS AND SOCIAL SCIENCES Vol. 10, No. 10, 2020, E-ISSN: 2222-6990 @ 2020 HRMARS

Table 8: Alternatives to plastic bags

\begin{tabular}{|l|r|r|}
\hline \multirow{2}{*}{ Variables/Category } & \multicolumn{2}{|c|}{ Cloth bags } \\
\cline { 2 - 3 } Sex & Nor & \\
Male & 68 & $51.91 \%$ \\
Female & 19 & $45.24 \%$ \\
\hline Educational Status & & \\
Illiterate & 2 & $50 \%$ \\
Primary Education & 3 & $33.33 \%$ \\
High School Education & 24 & $45.28 \%$ \\
Higher Education & 58 & $54.21 \%$ \\
\hline Age Group & & \\
$<20$ years & 27 & $58.70 \%$ \\
20-29 years & 49 & $49.49 \%$ \\
30-39 years & 8 & $38.09 \%$ \\
$\geq 40$ years & 3 & $42.86 \%$ \\
\hline Occupation & & \\
Student & 63 & $55.26 \%$ \\
Gov't Employee & 3 & $25 \%$ \\
Private & 13 & $39.39 \%$ \\
Others & 8 & $57.14 \%$ \\
\hline
\end{tabular}

\section{Limitations to the Finding}

The study was conducted in the selected region with limited population out of which majority of the correspondents was consisting of males. To collect comprehensive and precise data, it is important to gather statistics from the whole population but it was not the case with the mentioned study. Besides this, if data is collected from a limited population, the categories of correspondents whose data is collected should be based on the ratio of their presence in a certain region. Females' unwillingness for participation because of society's culture was major resistance in the collection of unbiased data.

\section{Conclusion}

Although the majority of the respondents considered plastic bags as a major problem for which they have also recommended the solutions in the form of alternative bags made up of cloth, paper and fibre. To implement the solution, the majority of the participants said that increase in awareness can help to curb the problem. On the part of the government, this can be done by empowering shopkeepers/retailers, who are the source of providing plastic bags, can be advised not to give plastic bags to their customers. Citizens can be convinced to avoid using or taking plastic bags from the shopkeepers that can stop them to purchase these bags. Manufacturers can be assisted by providing them with the alternatives at low cost and increasing the taxes on raw materials used for the production of plastic bags. The government should make new strategies to ban the usage and productions of plastic bags in the twin-city. Strangely, most of the population at Islamabad and Rawalpindi are educated but they do not bother about the harmful effects of plastic bags. It requires a massive awareness campaign for avoiding the use of plastic bags and the city administration should 
INTERNATIONAL JOURNAL OF ACADEMIC RESEARCH IN BUSINESS AND SOCIAL SCIENCES Vol. 10, No. 10, 2020, E-ISSN: 2222-6990 @ 2020 HRMARS

continuously monitor the sale and production of plastic bags. Similarly, universities, colleges, schools and hospitals should become a role model in this regard.

\section{References}

Abbas, J. (2019). Impact of total quality management on corporate sustainability through the mediating effect of knowledge management. Journal of Cleaner Production, 244, 118806. https://do.org/10.1016/j.jclepro.2019.118806

Abbas, J. (2020a). Impact of total quality management on corporate green performance through the mediating role of corporate social responsibility. Journal of Cleaner Production, 242, 118458. https://doi.org/10.1016/j.jclepro.2019.118458

Abbas, J. (2020b). Service Quality in Higher Education Institutions: Qualitative Evidence from the Students' Perspectives using Maslow's Hierarchy of Needs. International Journal of Quality and Service Sciences. https://doi.org/10.1108/IJQSS-02-2020-0016

Abbas, J., Mahmood, H. K., \& Hussain, F. (2015). Information security management for small and medium size enterprises. Science International-Lahore, 27(3), 2393-2398.

Abbas, J., Muzaffar, A., Mahmood, H. K., Ramzan, M. A., \& Rizvi, S. S. ul H. (2014). Impact of Technology on Performance of Employees (A Case Study on Allied Bank Ltd, Pakistan). World Applied Sciences Journal, 29(2), 271-276.

Abbas, J., Muzaffar, A., Shoaib, M., \& Mahmood, H. K. (2014). Do Business Schools Really Fulfill Industry Requirements? An Investigation of Industrial Performance of Business Graduates. World Applied Sciences Journal, 31(7), 1378-1384.

Abbas, J., \& Sagsan, M. (2019). Identification of key employability attributes and evaluation of university graduates' performance: Instrument development and validation. Higher Education, Skills and Work-Based Learning, 10(3), 449-466.

https://doi.org/10.1108/HESWBL-06-2019-0075

Abbas, J., \& Sagsan, M. (2019). Impact of knowledge management practices on green innovation and corporate sustainable development: A structural analysis. Journal of Cleaner Production, 229, 611-620. https://doi.org/10.1016/j.jclepro.2019.05.024

Adane, L., \& Muleta, D. (2011). Survey on the usage of plastic bags, their disposal and adverse impacts on environment: A case study in Jimma City, Southwestern Ethiopia. Journal of Toxicology and Environmental Health Sciences, 3(8), 234-248.

Baloch, S. M. (2019, August 23). Pakistan expands ban on plastic bags as inspectors are caught in shop spat. The Guardian. https://www.theguardian.com/globaldevelopment/2019/aug/23/pakistan-expands-ban-plastic-bags

Capital Development Authority. (2020, March 11). Facts \& Statistics [Information related to Islamabad]. Capital Development Authority Islamabad.

http://cda.gov.pk/about_islamabad/vitalstats.asp\#

Chaudhuri, D. T. (2016). USAGE OF PLASTIC CARRY BAGS AND IMPACT ON ENVIRONMENT, IN MUMBAI. Abhinav Publication, 5(3), 6.

Clapp, J., \& Swanston, L. (2009). Doing away with plastic shopping bags: International patterns of norm emergence and policy implementation, Environmental Politics. 315-332.

Ellis, S., Kantner, S., Saab, A., \& Watson, M. (2005). PLASTIC GROCERY BAGS: 19.

Greener Ideal Staff. (2018). How Do Plastic Bags Affect Our Environment? [Environmental News and Green Living Publication]. Greener Ideal. https://greenerideal.com/news/environment/0613how-do-plastic-bags-affect-our-environment/ 
INTERNATIONAL JOURNAL OF ACADEMIC RESEARCH IN BUSINESS AND SOCIAL SCIENCES

Vol. 10, No. 10, 2020, E-ISSN: 2222-6990 @ 2020 HRMARS

Habib, M., Abbas, J., \& Noman, R. (2019). Are human capital, intellectual property rights, and research and development expenditures really important for total factor productivity? An empirical analysis. International Journal of Social Economics, 46(6), 756-774.

https://doi.org/10.1108/IJSE-09-2018-0472

Imran, M., \& Abbas, J. (2020). The Role Of Strategic Orientation In Export Performance Of China Automobile Industry. In Handbook of Research on Managerial Practices and Disruptive Innovation in Asia (pp. 249-263). IGI Global.

Jalil, M. A. J., \& Mian, N. (2011). Using Plastic Bags and Its Damaging Impact on Environment and Agriculture. 1-16.

Jalil, Md. A., Mian, Md. N., \& Rahman, M. K. (2013). Using Plastic Bags and Its Damaging Impact on Environment and Agriculture: An Alternative Proposal. International Journal of Learning and Development, 3(4), 1. https://doi.org/10.5296/ijld.v3i4.4137

Kumar, P. (2018). Impact of Plastic on the Environment. International Journal of Trend in Scientific Research and Development, Volume-2(Issue-2), 471-474.

https://doi.org/10.31142/ijtsrd9421

Mahmood, H. K., Hashmi, M. S., Shoaib, D. M., Danish, R., \& Abbas, J. (2014). Impact of TQM Practices on Motivation of Teachers in Secondary Schools Empirical Evidence from Pakistan. Journal of Basic and Applied Scientific Research, 4(6), 1-8.

Mahmood, H. K., Hussain, F., Mahmood, M., Kumail, R., \& Abbas, J. (2020). Impact of E-Assessment at Middle School Students' Learning - An Empirical study at USA Middle School Students. International Journal of Scientific \& Engineering Research, 11(4), 1722-1736.

Moharam, R., \& Maqtari, M. A. A. (2014). The Impact of Plastic Bags on the Environment: A field Survey of the City Of Sana'a And The Surrounding Areas, Yemen. International Journal of Engineering Research and Reviews, 2(4), 10.

Mulder, K. F. (2013). Impact of New Technologies: How to Assess the Intended and Unintended Effects of New Technologies? In Handbook of Sustainable Engineering (pp. 817-835). Springer, Dordrecht. https://link.springer.com/referenceworkentry/10.1007\%2F978-1-40208939-8_35

Nielsen, T. D., Hasselbalch, J., Holmberg, K., \& Stripple, J. (2019). Politics and the plastic crisis: A review throughout the plastic life cycle. WIREs Energy Environment, 9(1), 1-18.

Pakistan Bureau of Statistics. (2020, March 11). Provisional Summary Results of 6th Population and Housing Census-2017 [Statistics]. Pakistan Bureau of Statistics.

http://www.pbs.gov.pk/content/provisional-summary-results-6th-population-and-housingcensus-2017-0

Shah, S. (2019, August 5). Pakistan will become 128th country to ban use of plastic bags on 14th. The News International. https://www.thenews.com.pk/print/508417-pakistan-will-become128th-country-to-ban-use-of-plastic-bags-on-14th

Sugii, T. (2008). Plastic Bag Reduction: Policies to Reduce Environmental Impact.

Thompson, R. C., Moore, C. J., vom Saal, F. S., \& Swan, S. H. (2009). Plastics, the environment and human health: Current consensus and future trends. Philosophical Transactions of the Royal Society B: Biological Sciences, 364(1526), 2153-2166.

https://doi.org/10.1098/rstb.2009.0053

V, R., \& HR, S. (2011). Plastic bags - threat to environment and cattle health: A retrospective study from Gondar city of Ethiopia. The Official J. Inst. Integr. Omics Appl. Biotech. J. 7-12.

Williamson, L. (2003). It's Not My Bag, Baby. On Earth: Environmental Politics People. 25(2), 32-34. 